\title{
Proteasome Subunit Alpha Type-5
}

National Cancer Institute

\section{Source}

National Cancer Institute. Proteasome Subunit Alpha Type-5. NCI Thesaurus. Code C120067.

Proteasome subunit alpha type-5 (241 aa, $\sim 26 \mathrm{kDa}$ ) is encoded by the human PSMA5 gene. This protein is involved in ATP-dependent protein catabolism. 